\title{
ORANI-SL - A Computable General Equilibrium Model to Assess the Climate Change Impacts on Agriculture in Sri Lanka Developing a CGE database for ORANI-SL
}

Walimuni Chamindri Sewanka Mendis Abeysekara ( $\Delta$ chamindri.abeysekara@gmail.com ) University of New England Faculty of Economics Business and Law: University of New England https://orcid.org/0000-0002-3997-553X

Mahinda Siriwardana

University of New England Faculty of Economics Business and Law: University of New England Samuel Meng

University of New England Faculty of Economics Business and Law: University of New England

Research

Keywords: Agriculture, Climate Change, Computable General Equilibrium, Irrigation, Land

Posted Date: March 5th, 2021

DOl: https://doi.org/10.21203/rs.3.rs-266102/v1

License: (c) (i) This work is licensed under a Creative Commons Attribution 4.0 International License.

Read Full License 


\title{
ORANI-SL - A Computable General Equilibrium Model to Assess the Climate Change Impacts on Agriculture in Sri Lanka
}

\section{Developing a CGE database for ORANI-SL}

\author{
Walimuni Chamindri Sewanka Mendis Abeysekara ${ }^{1,2}$ \\ Mahinda Siriwardana ${ }^{1}$, Samuel Meng ${ }^{1}$ \\ ${ }^{1}$ University of New England - Australia, ${ }^{2}$ University of Ruhuna - Sri Lanka \\ E Mail-chamindri.abeysekara@gmail.com \\ ORCiD- https://orcid.org/0000-0002-3997-553X
}

\section{Declarations \\ Funding: Not applicable}

Conflicts of interest/Competing interests: The authors have no relevant financial or non-financial interests to disclose.

Availability of data and material: Data and materials comply with standards and available on request.

Code availability: software application or custom code comply with field standards.

Authors' contributions: W C S M Abeysekara - primary author, M. Siriwardana and Samuel Meng - Supervision

Ethics approval: Not applicable

Consent for publication: All authors give their consent for publication

\begin{abstract}
$\underline{\text { Abstract }}$
This paper presents a detailed technical description of features added to the standard ORANI model to construct a CGE for Sri Lanka, namely, ORANI- SL. The model distinguishes between rain-fed and irrigated agricultural land and introduces water as a production factor. In addition, the new production structure offers the option of substitution between rain-fed and irrigated agricultural lands. The paper also describes the model's database and the steps of the data transformation process from the latest available input-output table of Sri Lanka to the ORANI-SL database, which is necessary for model simulation. The new model could be used to analyse the economy wide
\end{abstract}


impacts of climate change in Sri Lanka, study the economic implications of increased irrigation capacity or sustainable water usage in Sri Lanka, and evaluate the efficacy of various other adaptive strategies to cope with the impacts of climate change. In addition this model can be easily adapted to another country.

Key words: Agriculture, Climate Change, Computable General Equilibrium, Irrigation, Land

\section{Introduction}

Agriculture is globally one of the major forms of human activity and livelihood, employing available land and water resources to feed the population. Undeniably, research in the related disciplines of soil chemistry, plant biochemistry, and environment studies, as well as the development of technology has enabled the agricultural sector to boost its production during the past century. Yet, the uneven distribution of these benefits has not provided a proper solution for hunger and poverty in some parts of the world (Barrett, 2010). Currently, the agricultural sector faces a monumental challenge to feed the growing global population, projected to reach nine billion by 2050 (Godfray et al., 2010).

The agricultural sector and its production are intrinsically interlinked with climate and the environment. Topping all existing global challenges to food production and agroindustry growth, is the impact of climate change. The agricultural sector will experience a greater economic impact from climate change compared to any other industries (Cline, 2007; Mendelsohn, 2008). In addition, rain-fed agriculture is still the main livelihood of the majority of the rural populations of developing countries. Predicted rainy seasons with sufficient rainfall and optimum temperatures will continue to enhance production ensuring food security. However, unpredictability of rainy seasons and the predicted rainfall shortfalls will reduce yield, leading to food insecurity. As it is both an island in the Indian Ocean and a developing nation, Sri Lanka is highly vulnerable to changes in climate and the economic impacts of climate change. It is evident from existing literature that the mean annual temperature and extreme weather events on the island are on the increase, and the rainfall patterns are changing, making them unpredictable (Esham \& Garforth, 2013; Panabokke \& Punyawardena, 2010). Many studies on climate change impacts have clearly elucidated that the changes in climate in Sri Lanka have directly and indirectly affected the agricultural sector, imposing significant consequences for the economy and national food security 
(Ahmed \& Suphachalasai, 2014; De Costa, 2008, 2010; De Silva, 2009; Eeswaran, 2018; Esham \& Garforth, 2013; Premalal, 2009). However, the implementation of specific planned developments in the agricultural sector and its productivity are regarded as crucial in achieving sustainable development goals in developing countries, and Sri Lanka is no exemption.

Expansion of irrigated land areas will ensure the availability of the right volume of water at the right time for agricultural production and reduce the risk of production losses due to rain-water unpredictability. Moreover, the water demand is projected to increase in the future, particularly due to climate change (Berrittella, Hoekstra, Rehdanz, Roson, \& Tol, 2007). Aside from the impact of climate change, the scarcity of land and water resources offers very limited options for expanding the arable land areas and increasing food production. Thus, quantitative assessments on the effects of alternative investment options and adaptation strategies, such as promoting irrigated agriculture, have become vital to counter the agricultural and economic challenges and impacts of climate change.

According to the Food and Agriculture Organization of the United Nations, agriculture accounts for 70 percent of global water withdrawal and 90 percent of water consumption (Kohli, Frenken, \& Spottorno, 2010). Moreover, irrigated agriculture, which covers 20 percent of the world's agricultural land, contributes about 40 percent of world crop production (Kohli et al., 2010). Under such circumstances, it is vital to control and optimise water distribution and consumption in the agricultural sector as an adaptation strategy against climate change. In contrast, ineffectual water-usage policies providing water as an under-priced commodity or free resource have hindered the efficient distribution and usage of water resources. As national budgets and annual financial expenditure returns do not usually indicate water as a disaggregated component, as there are no recorded economic transactions related to water, this has limited the inclusion of water resources in economic models.

Despite these challenges, the Computable General Equilibrium (CGE) model, an accepted economic modelling approach, has been used by many scholars for climate change impact and adaptation assessments. CGE models can assess the impact of climate change on the agricultural sector by considering its interactions with other economic sectors. CGE models can determine the impact of climate change on the whole economy and evaluate the impact of different adaptation strategies. This paper presents a development of the ORANI- G model known as ORANI-SL, which 
introduces water as a factor of agricultural production and distinguishes between rainfed and irrigated agricultural land. It facilitates the assessment of adaptation strategies and alternative investment options, as to how these meet the challenges of climate change impacts on the agricultural sector in Sri Lanka and thereby the whole economy of the nation.

The paper is structured as follows: the first part of the paper reviews the literature on similar economic models. The second section explains in detail the revised version of the ORANI-SL model. The third section describes the database development, and the final section presents a conclusion.

\section{Literature Review}

Scholars have used economic models to investigate numerous water-related issues, such as its availability and usage in the agricultural sector and water policy. Partial equilibrium and CGE models have been applied to the analysis of similar water-related issues. Partial equilibrium methods can analyse water-related issues in a particular sector, assuming that it has no impact on other economic sectors, while CGE models can analyse impacts on the whole economy.

Nevertheless, incorporating water factors into a CGE model is challenging due to the following factors. The agricultural sector consumes a major portion of water for production, and it is natural to consider water as a factor within the production function. However, as water is generally a non-market commodity it is difficult to calibrate the parameters which determine the marginal productivity of water for different sectors to include in a CGE model. Many input-output tables (I-O tables) are available for water collection, treatment, and supply, including the I-O table of Sri Lanka which records the water distribution transactions to the other industries. However, these industries do not produce water and prices do not reflect the real production costs. Moreover, it is difficult to calculate the exact amount of rain-water and ground-water used for agricultural production, which also complicates incorporating water factors into a CGE model.

To overcome these challenges, scholars have used different approaches to incorporate the water component into CGE models. Berrittella et al. (2007), Sahlén (2008) and Tirado, Gomez, and Lozano (2006) introduced the concept of a water industry into the model, This method transforms rough water into effective water as an exogenous intermediate input for production and consumption. Another approach has been to embed the value of water within the value of land, assuming the source or supply of 
water to be a factor that determines soil characteristics, and thereby land value (Calzadilla, Rehdanz, \& Tol, 2010). One group of researchers used agronomic studies to obtain water productivity values to include in CGE models (Roson \& Sartori, 2015). Calzadilla, Rehdanz, Roson, Sartori, and Tol (2017) classified water-related simulation experiments into two categories. The CGE model has been used to assess the economy wide impacts due to water resource changes driven by climate change (Calzadilla, Zhu, Rehdanz, Tol, \& Ringler, 2013; Roson \& Sartori, 2015; Taheripour, Hertel, \& Liu, 2013), as well as to evaluate the impact of economic policies on water demand, consumption, etc.(Berrittella et al., 2007; Calzadilla, Rehdanz, \& Tol, 2011b; Gomez, Tirado, \& Rey-Maquieira, 2004).

As the ORANI-SL model differentiates between rain-fed and irrigated agriculture by introducing water as a factor of production embedded in land rental, this study mainly reviews models that considered water as a factor of the land component. Such studies have been applied both on a regional and global scale.

Berck, Robinson, and Goldman (1991), followed by Robinson and Gehlhar (1995), Mukherjee (1996), Seung, Harris, MacDiarmid, and Shaw (1998), and Decaluwe, Patry, and Savard (1999) all embedded the water component into land rental to analyse the regional water-related issues in the '90s. Berck et al. (1991) analysed the impact of reduced amounts of water as an agricultural input on aggregate Gross Domestic Production (GDP) for the southern portion of the San Joaquin Valley in California, using a multi-level function production technology for the agricultural sector with low and high elasticity variants. The agricultural sectoral capital varies with land use in the low elasticity variant and is fixed in the high elasticity variant. Robinson and Gehlhar (1995) and Mukherjee (1996) used a similar production function to analyse the efficiency of land and water use economic policies. At the top level of the nested structure of the sectoral production function, the sectoral output is a linear function of real value added and intermediate inputs. The intermediate inputs are required as fixed input-output coefficients and real value added is a constant elasticity of substitution (CES) function of primary inputs (labour, capital, and land/water aggregate), where the land/water aggregate is a linear aggregation. Seung et al. (1998) used a regional CGE model to assess the impact of water reallocation from agricultural to recreational use in rural Nevada and California. The production function has a quadruple- nested structure. At the bottom level, water and acreage are combined in fixed proportions to produce land. Capital and land is then combined with a CES function to produce the capital/land 
aggregate, and another CES function is used to produce value added by combining labour and capital/land aggregate. At the top-level, the output is a linear function of intermediates and value added. Decaluwe et al. (1999) analysed different water pricing schemes in Morocco. The agricultural production function consists of a four-level nested structure. At the bottom level, land and capital are combined with a CES function to produce land and capital composite, and another CES function is used to combine water and fertilizer to produce intermediate inputs.

Diao and Roe (2000), Gomez et al. (2004), D. C. Peterson, Dwyer, Appels, and Fry (2004) D. Peterson, Dwyer, Appels, and Fry (2005), van Heerden, Blignaut, and Horridge (2008), Mark Horridge and Wittwer (2008) and P. Dixon, Rimmer, and Wittwer (2009) all used regional CGE models to analyse water-related issues in the 2000s. (Table 1).

Table 1 : Literature Review on Regional CGE-Water Models

\begin{tabular}{|c|c|c|c|c|}
\hline Author & $\begin{array}{l}\text { Modelling } \\
\text { Approach } \\
\text { (region) }\end{array}$ & $\begin{array}{l}\text { Research question } \\
\text { and results }\end{array}$ & Key points in Production function & Role of water \\
\hline $\begin{array}{l}\text { Gomez et } \\
\text { al. (2004) }\end{array}$ & $\begin{array}{l}\text { Static regional } \\
\text { model } \\
\text { (Balearic } \\
\text { Islands, Spain) }\end{array}$ & $\begin{array}{l}\text { Q: To analyse the } \\
\text { welfare gains due to } \\
\text { the allocation of } \\
\text { water rights. } \\
\text { R: Allocation of } \\
\text { water rights are } \\
\text { more advantageous } \\
\text { than other } \\
\text { alternatives. }\end{array}$ & $\begin{array}{l}\text { Used five production factors (land, } \\
\text { labour, capital, water and sea water). } \\
\text { Land is used only in the agricultural } \\
\text { sector. Underground water and } \\
\text { energy are combined at the bottom } \\
\text { level to produce agricultural water. }\end{array}$ & $\begin{array}{l}\text { Water supply } \\
\text { assumed to be } \\
\text { fixed. Water is } \\
\text { used by the } \\
\text { agricultural } \\
\text { sector } \\
\text { production, } \\
\text { households for } \\
\text { consumption and } \\
\text { as } \\
\text { intermediate } \\
\text { input in other } \\
\text { industries. }\end{array}$ \\
\hline $\begin{array}{l}\text { D. } \\
\text { Peterson } \\
\text { et al. } \\
(2005)\end{array}$ & $\begin{array}{l}\text { TERM-Water } \\
\text { CGE model } \\
\text { (Southern } \\
\text { Murray- } \\
\text { Darling Basin, } \\
\text { Australia) }\end{array}$ & $\begin{array}{l}\text { Q: To analyse the } \\
\text { impact of water } \\
\text { trading expansion of } \\
\text { irrigation water. } \\
\text { R: Water trading } \\
\text { within irrigation } \\
\text { districts is more } \\
\text { beneficial than } \\
\text { expansion of trade } \\
\text { between regions. }\end{array}$ & $\begin{array}{l}\text { Considered irrigation water as an } \\
\text { endowment in production and the } \\
\text { production cost of the irrigation } \\
\text { water is not a factor in the model. } \\
\text { Irrigation water is combined with } \\
\text { other non-water inputs with a CES } \\
\text { function at the top level of the nested } \\
\text { production function. }\end{array}$ & $\begin{array}{l}\text { Water supply is } \\
\text { fixed } \\
\text { exogenously. } \\
\text { Water usage is } \\
\text { limited to the } \\
\text { agricultural } \\
\text { sector. }\end{array}$ \\
\hline
\end{tabular}




\begin{tabular}{|c|c|c|c|c|}
\hline $\begin{array}{l}\text { van } \\
\text { Heerden } \\
\text { et al. } \\
(2008)\end{array}$ & $\begin{array}{l}\text { static } \\
\text { computable } \\
\text { general } \\
\text { equilibrium } \\
\text { model } \\
\text { UPGEM } \\
\text { (South Africa) }\end{array}$ & $\begin{array}{l}\text { Q: To analyse the } \\
\text { impact of new tax } \\
\text { policies on water } \\
\text { demand by forestry } \\
\text { and irrigated field } \\
\text { crops. } \\
\text { R: Tax on irrigated } \\
\text { field crops is } \\
\text { beneficial in the } \\
\text { long run. }\end{array}$ & $\begin{array}{l}\text { Raw water is combined with primary } \\
\text { factors and intermediate inputs, } \\
\text { together with a Leontief technology } \\
\text { function at the top level of the } \\
\text { production structure. }\end{array}$ & $\begin{array}{l}\text { Water users are } \\
\text { categorised into } \\
\text { three groups, } \\
\text { namely, } \\
\text { agricultural } \\
\text { sector, bulk users } \\
\text { of non-portable } \\
\text { water, and the } \\
\text { remaining } \\
\text { industries and } \\
\text { households. }\end{array}$ \\
\hline $\begin{array}{l}\text { P. Dixon } \\
\text { et al. } \\
(2009)\end{array}$ & $\begin{array}{l}\text { Dynamic CGE } \\
\text { model TERM } \\
-\quad \mathrm{H}_{2} \mathrm{O} \\
\text { (Australia) }\end{array}$ & $\begin{array}{l}\text { Q: To analyse the } \\
\text { impacts of inter- } \\
\text { regional water } \\
\text { trading (buyback } \\
\text { scheme) } \\
\text { R: Water rights } \\
\text { holders can increase } \\
\text { benefits by } \\
\text { increasing irrigation } \\
\text { water price. }\end{array}$ & $\begin{array}{l}\text { At the bottom level of the production } \\
\text { function unwatered irrigable land is } \\
\text { combined using a Leontief } \\
\text { technology function water to } \\
\text { produce irrigated land, which is } \\
\text { combine with irrigable land and dry } \\
\text { land using a CES function to } \\
\text { produce effective land. Total land is } \\
\text { produced by combining effective } \\
\text { land with cereal land using a CES } \\
\text { function. }\end{array}$ & $\begin{array}{l}\text { Water is used by } \\
\text { the agricultural } \\
\text { sector for } \\
\text { irrigation. There } \\
\text { are constraints on } \\
\text { the volume of } \\
\text { water traded } \\
\text { between regions } \\
\text { for irrigation. }\end{array}$ \\
\hline
\end{tabular}

\section{ORANI-SL Model}

ORANI-SL is a single country CGE model. The ORANI-SL model core follows the framework of the ORANl-G single country generic computable general equilibrium model (P. B. Dixon, 1982; J. Horridge, 2000). ORANI is a comparative static CGE model of the Australian economy, developed by the Centre of Policy Studies (CoPS) and Impact Project at Monash University in Australia (Mark Horridge, 2003). It was developed to analyse policy successes and failures in Australia. ORANI-G is an adapted version of ORANI, which has served as a foundation for the construction of many new models (Lkhanaajav, 2016).

Since the study's primary focus is on the agricultural sector, the model was modified by disaggregating agricultural land into irrigated land and rain-fed land. Achieving this primary fundamental modification involved the following three main steps:

The first step required calculating the model's data requirements - the traditional I-O table is not sufficient for fitting the irrigation-oriented ORANI -SL model since it does not distinguish between irrigated and rain-fed land. Therefore, some detailed statistics on irrigated and rain-fed land usage by agricultural activities, data on land rentals, and 
certain elasticity parameters were collected from the Department of Census and Statistics, Ministry of Agriculture, Department of Irrigation and existing literature. Theoretical modifications were then made to the standard ORANI-G model by expressing the equations in a suitable form to construct the ORANI-SL model (to build a model within GEMPACK, it is necessary to prepare a TABLO Input file containing the equations of the model). Finally, a database for the ORANI-SL was developed based on the Sri Lankan I-O table and other collected data.

As the major modification involved the production structure, an overview of the model's new adaptive production structure follows (Figure 1). At the top nest of the production function, the output is a Leontief function of intermediate inputs and primary factors. At the Armington nest, each intermediate input is a CES combination of imported and domestic goods. At the primary factor nest, land, labour, and capital are combined using a CES function to produce primary factors. At the bottom level, labour is a CES function of skilled and unskilled labour and the land is a CES function of irrigated and rain-fed land (Figure 1).

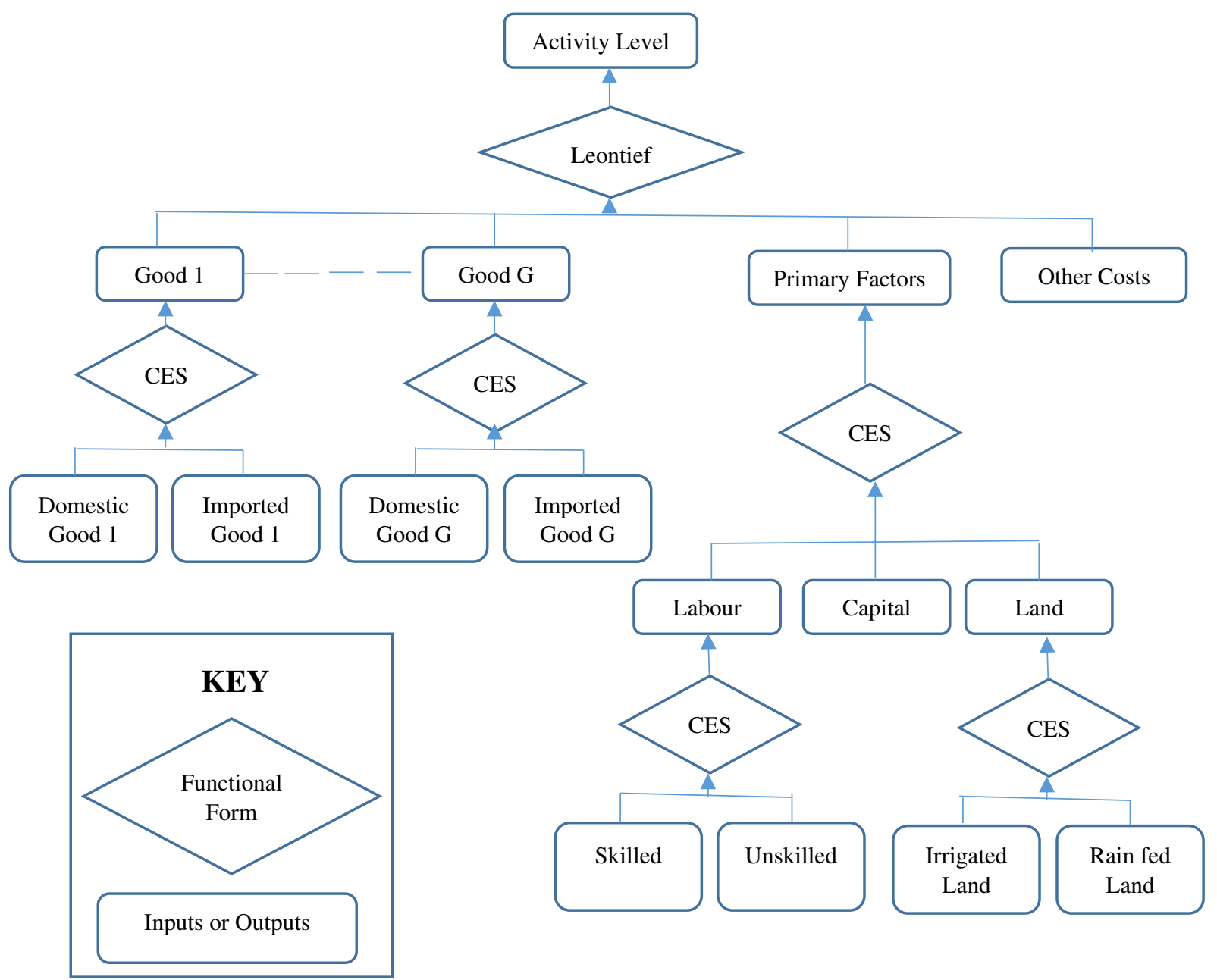


Figure 1 : Model Production Function

The ORANI-G model consists of a multitude of equations, fully explained by Mark Horridge (2003). To implement the ORANI-SL model, some equations from the ORANI-G were altered, and certain new equations were added, for example, the demand and cost functions for the rain-fed and irrigated land composite. As illustrated in figure 1, a CES function is used to represent the producer's behaviour in selecting irrigated land or rain-fed land as an input. J. Horridge (2000) has explained the percentage change equations of a CES nest function used in ORANI-G in detail. Following J. Horridge (2000), demand and cost functions for rain-fed and irrigated land composite were added to the model and coded in TABLO language according to the ORANI-SL notation (ORANI-SL code is available on request). The TABLO coding of the nested structure in figure 1, predominantly focused on the land CES function as it forms the novel addition to the model, is attached in the annex 1.

In the ORANI-SL model, it is also assumed that rain-fed lands can be converted into irrigation lands by applying water. Elasticity of substitution values can easily be obtained from the GTAP-W model provided for the South Asian region (Calzadilla, Rehdanz, \& Tol, 2011a). However, it is more appropriate to calculate the elasticity of substitution values specific to Sri Lanka. Therefore, the elasticity of substitution between irrigated land and rain-fed land was calculated using the price elasticity value of water estimated by Dharmaratna and Parasnis (2010) for Sri Lanka. Calculations were done using the following equations:

The two-input production function is represented in the following equation;

$$
Y=f(X, Z)
$$

Where, $\mathrm{Y}$ is the output, $\mathrm{z}$ is the water input and $\mathrm{x}$ all other inputs. Considering $\mathrm{p}$ as the composite price of all the other inputs and $r$ as the price of water, the cost function can be expressed as;

$$
C=p X+r Z
$$

According to production efficiency, the marginal rate of technical substitution (RTS) equals the price ratio of the two inputs; 


$$
\frac{f_{x}}{f_{z}}=\frac{p}{r}
$$

If we consider equation 1 as the CES function below,

$$
Y=\left(X^{-\rho}+Z^{-\rho}\right)^{-1 / \rho}
$$

The above CES function is defined for $\rho>-1, \rho \neq 0$, positive levels of inputs, continuous, differentiable, monotonic and strictly quasi-concave, and exhibits constant returns to scale (Gohin \& Hertel, 2003).

Accordingly;

$$
\mathrm{RTS}=\frac{f_{x}}{f_{z}}=\frac{Z^{\rho+1}}{X^{\rho+1}}=\frac{p}{r}
$$

If we consider two different water prices as $\mathrm{r}$ and $\mathrm{r}(1+\delta)$, the above equation can be expressed as,

$$
\begin{aligned}
& \frac{Z_{1}{ }^{\rho+1}}{X^{\rho+1}}=\frac{p}{r}, \\
& \frac{Z_{2}{ }^{\rho+1}}{X^{\rho+1}}=\frac{p}{r(1+\delta)}
\end{aligned}
$$

Considering equations 6 and 7;

$$
Z_{1}^{\rho+1}=Z_{2}^{\rho+1}(1+\delta)
$$

Price elasticity of demand can be represented as;

$$
e_{Z, r}=\frac{r \Delta Z}{Z \Delta r}
$$

Equation 9 can be expressed as;

$$
e_{Z, r}=\frac{r\left(Z_{2}-Z_{1}\right)}{Z_{1}(r(1+\delta)-r)}
$$

Therefore,

$$
Z_{2}=Z_{1}\left(1+e_{Z, r} \delta\right)
$$

Combining equations 8 and 11, elasticity of substitution can be given as the function of the price elasticity of demand for water;

$$
\rho=\frac{\ln (1+\delta)}{\ln \left(1+e_{Z, r} \delta\right)}-1
$$


The estimated value for price elasticity demand for water as calculated by Dharmaratna and Parasnis (2010) is -0.15 . Using equation 12, the elasticity of substitution between irrigated land and rain-fed land was calculated as 0.05 . The elasticity of substitution used in the GTAP-W model for the South Asia region is 0.06. The ORANI - SL model, however, will incorporate the calculated value for Sri Lanka based on the elasticity of substitution between irrigated and rain-fed lands.

The model was then validated to ensure its accuracy. A real homogeneity test was conducted to establish whether the model satisfied the constant returns to scale condition. All real variables in the exogenous list were shocked by $\mathrm{X} \%$ and examined as to whether all were changed by $\mathrm{X} \%$, while the nominal variables remained unchanged in the solution. The ORANI-SL model satisfied the above homogeneity test.

\section{Database Development}

\section{Input-Output Data Tables}

Implementation of the CGE model requires two types of principal sources of data, namely, an economy wide I-O table or Social Accounting Matrix (SAM) and a set of values for the selected elasticity parameters. The I-O table represents the economic status quo, which is the initial solution of the model (P. Dixon et al., 2009). The most updated I-O table, compiled by the Department of Census and Statistics (DCS) in Sri Lanka, was used to develop the ORANI-SL model.

The first set of tables developed by the DCS is known as the "supply-and-use tables" (SUTs), which balance the supply and use of each product in the economy. These tables describe the process of allocating various goods and services obtained locally or imported for various intermediate or final uses, including exports. These matrices provide a solid framework to balance the supply and use of commodities in an economy. These two tables are then transformed into a single table, in which row and column totals are equal to compile an economy-wide I-O table.

The simplified version of Sri Lanka's I-O table is demonstrated in Table 2. It consists of three quadrants (Q1, Q2, and Q3). The first quadrant (Q1) shows the goods and services flow between domestic industries. Q1 column values indicate the amounts of intermediate inputs used by each industry, and the row values the proportion of each industry's output absorbed by the other industries in the economy. Simply, each cell (row $i$ and column $j$ ) in Q1 specifies the amount of industry $i$ 's output absorbed by the industry $j$ for its current production. All the data in Q1 is valued at the basic price. The 
second quadrant (Q2) in Table 2 shows the disposition of industry i's output for final consumption, capital formation, and exports. The summation of values in each row of Q1 and Q2 provides the total usage of each industry's goods and services. Quadrant three (Q3) in Table 2 shows the entries usually referred to as value additions. These include compensation for employees, taxes on production, consumption of fixed capital, and operating surpluses. 
Table 2 : Basic Format of Sri Lanka's I-O Table

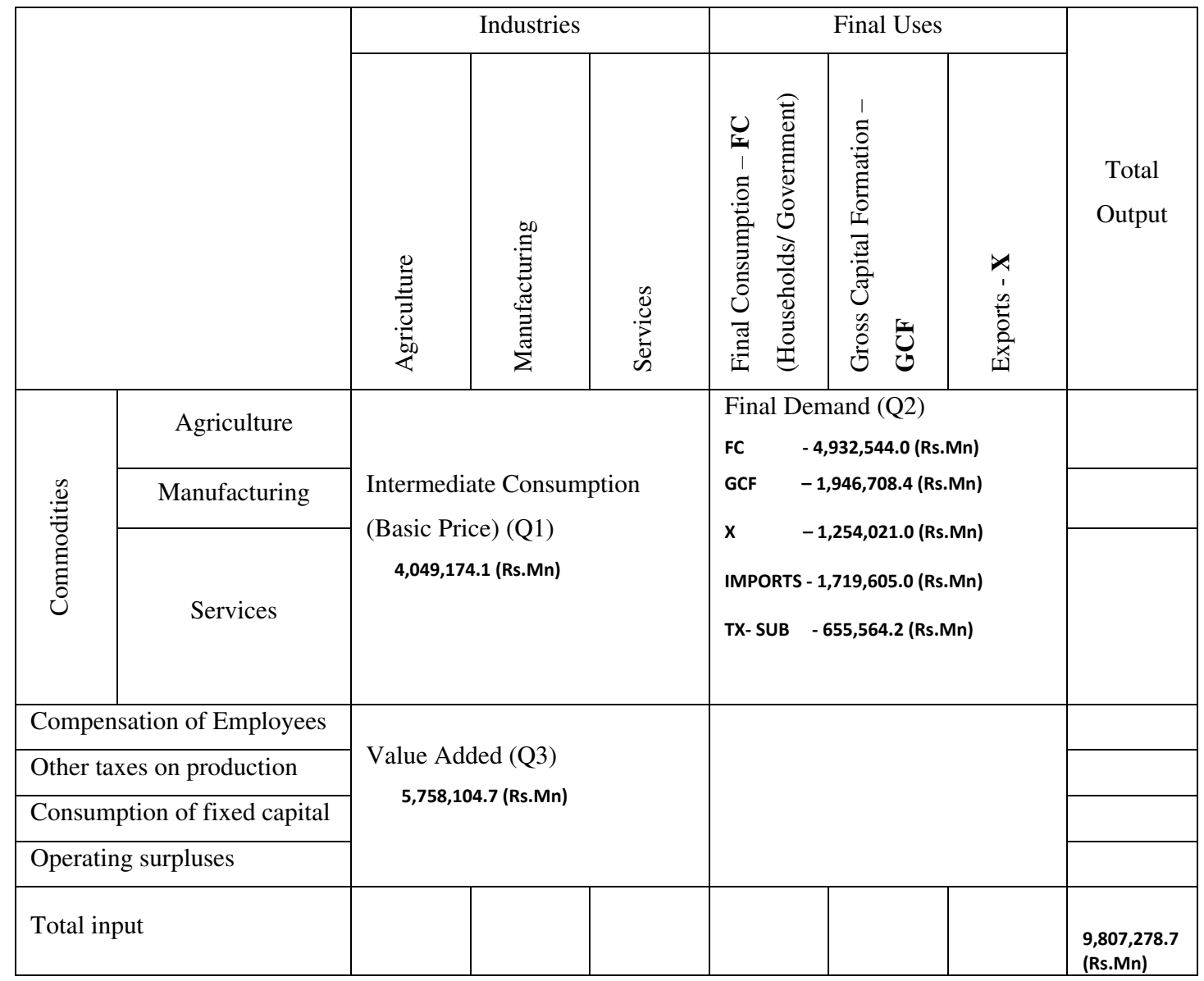

The USE table compiled by the DCS is divided into three, namely, the total use table, domestic use table, and the import use table (Tables 3, 4, 5, and 6). A separate row in each table indicates the values of net indirect taxes or subsidies, which represent the payment made to or received from the government for a single unit of good or service in the intermediate or final demand. In the SUTs and I-O table, basic import flows' values include the cost insurance freight values (cif).

Since this study uses the ORANI-NM (no margins) model, margins were treated as services in the USE matrix (e.g., transport margin is viewed as transport service). Therefore, the margin values of the transport and trade were also added to the base value of transport and trade. Similarly, margin values were also incorporated into the supply matrix, in order to leave the margin matrices as null. 
Table 3 : Total USE Table

\begin{tabular}{|l|l|l|l|l|l|l|l|l|c|}
\hline \multirow{2}{*}{$\begin{array}{c}\text { Total USE } \\
\text { table }\end{array}$} & \multicolumn{3}{|c|}{ Intermediate Demans } & \multicolumn{5}{c|}{ Final Demand } & \multirow{2}{*}{ otal } \\
\cline { 2 - 9 } & Agric. & Manufac. & Servic. & $\mathrm{H} / \mathrm{H}$ & Gov. & Invest. & Exports & Stocks & \\
\hline Agric. & $\mathrm{XXXX}$ & $\mathrm{XXXX}$ & $\mathrm{XXXX}$ & $\mathrm{XXXX}$ & $\mathrm{XXXX}$ & $\mathrm{XXXX}$ & $\mathrm{XXXX}$ & $\mathrm{XXXX}$ & $\mathrm{XXXXX}$ \\
\hline Manufac. & $\mathrm{XXXX}$ & $\mathrm{XXXX}$ & $\mathrm{XXXX}$ & $\mathrm{XXXX}$ & $\mathrm{XXXX}$ & $\mathrm{XXXX}$ & $\mathrm{XXXX}$ & $\mathrm{XXXX}$ & $\mathrm{XXXXX}$ \\
\hline Servic. & $\mathrm{XXXX}$ & $\mathrm{XXXX}$ & $\mathrm{XXXX}$ & $\mathrm{XXXX}$ & $\mathrm{XXXX}$ & $\mathrm{XXXX}$ & $\mathrm{XXXX}$ & $\mathrm{XXXX}$ & $\mathrm{XXXXX}$ \\
\hline Margins & $\mathrm{XXXX}$ & $\mathrm{XXXX}$ & $\mathrm{XXXX}$ & $\mathrm{XXXX}$ & $\mathrm{XXXX}$ & $\mathrm{XXXX}$ & $\mathrm{XXXX}$ & $\mathrm{XXXX}$ & $\mathrm{XXXXX}$ \\
\hline Indirect tax & $\mathrm{XXXX}$ & $\mathrm{XXXX}$ & $\mathrm{XXXX}$ & $\mathrm{XXXX}$ & $\mathrm{XXXX}$ & $\mathrm{XXXX}$ & $\mathrm{XXXX}$ & $\mathrm{XXXX}$ & $\mathrm{XXXXX}$ \\
\hline $\begin{array}{l}\text { Opp. } \\
\text { Surplus }\end{array}$ & $\mathrm{XXXX}$ & $\mathrm{XXXX}$ & $\mathrm{XXXX}$ & $\mathrm{XXXX}$ & $\mathrm{XXXX}$ & $\mathrm{XXXX}$ & $\mathrm{XXXX}$ & $\mathrm{XXXX}$ & $\mathrm{XXXXX}$ \\
\hline Labour & $\mathrm{XXXX}$ & $\mathrm{XXXX}$ & $\mathrm{XXXX}$ & $\mathrm{XXXX}$ & $\mathrm{XXXX}$ & $\mathrm{XXXX}$ & $\mathrm{XXXX}$ & $\mathrm{XXXX}$ & $\mathrm{XXXXX}$ \\
\hline Prod. Tax & $\mathrm{XXXX}$ & $\mathrm{XXXX}$ & $\mathrm{XXXX}$ & $\mathrm{XXXX}$ & $\mathrm{XXXX}$ & $\mathrm{XXXX}$ & $\mathrm{XXXX}$ & $\mathrm{XXXX}$ & $\mathrm{XXXXX}$ \\
\hline Total & $\mathrm{XXXXX}$ & $\mathrm{XXXXX}$ & $\mathrm{XXXXX}$ & $\mathrm{XXXXX}$ & $\mathrm{XXXXX}$ & $\mathrm{XXXXX}$ & $\mathrm{XXXXX}$ & $\mathrm{XXXXX}$ & $\mathrm{XXXXX}$ \\
\hline
\end{tabular}

Table 4: Domestic USE Table

\begin{tabular}{|c|c|c|c|c|c|c|c|c|c|}
\hline \multirow{2}{*}{$\begin{array}{l}\text { Domestic } \\
\text { USE table }\end{array}$} & \multicolumn{3}{|c|}{ Intermediate Demands } & \multicolumn{5}{|c|}{ Final Demand } & \multirow{2}{*}{ Total } \\
\hline & Agric. & Manufac. & Servic. & $\mathrm{H} / \mathrm{H}$ & Gov. & Invest. & Exports & Stocks & \\
\hline Agric. & XXXX & XXXX & XXXX & XXXX & XXXX & XXXX & XXXX & XXXX & XXXXX \\
\hline Manufac. & $\mathrm{XXXX}$ & XXXX & XXXX & XXXX & XXXX & XXXX & XXXX & XXXX & XXXXX \\
\hline Servic. & XXXX & XXXX & XXXX & XXXX & XXXX & XXXX & XXXX & XXXX & XXXXX \\
\hline Margins & $\mathrm{XXXX}$ & XXXX & XXXX & XXXX & XXXX & $\mathrm{XXXX}$ & XXXX & XXXX & XXXXX \\
\hline Indirect tax & $\mathrm{XXXX}$ & $\mathrm{XXXX}$ & $\mathrm{XXXX}$ & $\mathrm{XXXX}$ & $\mathrm{XXXX}$ & $\mathrm{XXXX}$ & $\mathrm{XXXX}$ & $\mathrm{XXXX}$ & $\mathrm{XXXXX}$ \\
\hline $\begin{array}{l}\text { Opp. } \\
\text { Surplus }\end{array}$ & $\mathrm{XXXX}$ & $\mathrm{XXXX}$ & $\mathrm{XXXX}$ & $\mathrm{XXXX}$ & $\mathrm{XXXX}$ & $\mathrm{XXXX}$ & $\mathrm{XXXX}$ & $\mathrm{XXXX}$ & $\mathrm{XXXXX}$ \\
\hline Labour & XXXX & $\mathrm{XXXX}$ & $\mathrm{XXXX}$ & XXXX & $\mathrm{XXXX}$ & XXXX & $\mathrm{XXXX}$ & XXXX & XXXXX \\
\hline Prod. Tax & $\mathrm{XXXX}$ & $\mathrm{XXXX}$ & $\mathrm{XXXX}$ & $\mathrm{XXXX}$ & XXXX & $\mathrm{XXXX}$ & $\mathrm{XXXX}$ & $\mathrm{XXXX}$ & XXXXX \\
\hline Total & XXXX & XXXX & XXXX & XXXX & XXXX & XXXX & XXXX & XXXX & XXXXX \\
\hline
\end{tabular}

Table 5: Import USE Table

\begin{tabular}{|c|c|c|c|c|c|c|c|c|c|}
\hline \multirow{2}{*}{$\begin{array}{c}\text { Import } \\
\text { USE table }\end{array}$} & \multicolumn{3}{|c|}{ Intermediate Demands } & \multicolumn{5}{|c|}{ Final Demand } & \multirow{2}{*}{ Total } \\
\hline & Agric. & Manufac. & Servic. & $\mathrm{H} / \mathrm{H}$ & Gov. & Invest. & Exports & Stocks & \\
\hline Agric. & XXXX & XXXX & XXXX & $\mathrm{XXXX}$ & $\mathrm{XXXX}$ & XXXX & XXXX & XXXX & XXXXX \\
\hline Manufac. & XXXX & XXXX & XXXX & XXXX & XXXX & XXXX & XXXX & XXXX & XXXXX \\
\hline Servic. & $\mathrm{XXXX}$ & $\mathrm{XXXX}$ & $\mathrm{XXXX}$ & $\mathrm{XXXX}$ & $\mathrm{XXXX}$ & $\mathrm{XXXX}$ & $\mathrm{XXXX}$ & $\mathrm{XXXX}$ & XXXXX \\
\hline Margins & $\mathrm{XXXX}$ & $\mathrm{XXXX}$ & $\mathrm{XXXX}$ & $\mathrm{XXXX}$ & $\mathrm{XXXX}$ & $\mathrm{XXXX}$ & $\mathrm{XXXX}$ & $\mathrm{XXXX}$ & XXXXX \\
\hline Indirect tax & 0 & 0 & 0 & - & - & - & - & - & $\mathrm{XXXXX}$ \\
\hline $\begin{array}{l}\text { Opp. } \\
\text { Surplus }\end{array}$ & 0 & 0 & 0 & - & - & - & - & - & XXXXX \\
\hline Labour & 0 & 0 & 0 & - & - & - & - & - & XXXXX \\
\hline Prod. Tax & 0 & 0 & 0 & - & - & - & - & - & $\mathrm{XXXXX}$ \\
\hline Total & $\mathrm{XXXXX}$ & XXXXX & XXXXX & XXXXX & XXXXX & XXXXX & XXXXX & XXXXX & XXXXX \\
\hline
\end{tabular}

Table 6: MAKE Matrix

\begin{tabular}{|l|l|l|l|l|}
\hline MAKE MATRIX & Agric. & Manufac. & Servic. & Total \\
\hline Agric. & Xxxxx & & & xxxxx \\
\hline Manufac. & & xxxxx & & Xxxxx \\
\hline Servic. & & & xxxxx & xxxxx \\
\hline Margins & Xxxxxx & xxxxx & xxxxx & xxxxx \\
\hline Total & Xxxxx & Xxxxx & Xxxxx & Xxxxx \\
\hline
\end{tabular}

The row totals in Tables 3,4, and 5 represent the number of total goods and services (Commodities "C") supplied by each industry at unit cost, while the column total denotes the total demand or the total amount of commodities absorbed by each industry ("I") for its current production. The simplified version of Sri Lanka's SUTs, exhibits 
three commodities and three industries, namely, "Agriculture," "Manufacturing," and "Services." Thus, the matrix is symmetric, having an equal number of commodities and industries. Similarly, this study employs a symmetric I-O table benchmarked for the year 2010, the most up-to-date I-O table published by the DCS, consisting of 127 industries and 127 commodities. A highly aggregated version of this I-O table based on real values can be found in Annex 2.

In the ORANI-G model, total demand must be equal to total domestic supply. Therefore, the column totals in the total USE table (Table 3) must be equal to the column totals of the MAKE matrix (Table 6), while the row totals of the domestic USE table (Table 4) must be equal to the row totals of the MAKE matrix (Table 6). Hence, the MAKE matrix denotes each commodity's domestic production level (row headings) by each industry (column headings).

In addition to the I-O table, different elasticity data, such as elasticities for substitution between domestic and imported sources (Armington elasticities) of commodities, elasticities of substitution between primary factors, household expenditure parameters, and export demand elasticities, are required to implement the model. Readily available data for elasticities were obtained from the GTAP database.

\section{I-O Table data transformation into the ORANI-SL format}

The next requirement is to transform the data in Sri Lanka's I-O table into the ORANISL format (Figure 3) to implement the model. As the ORANI-G model is accessible for modification, the ORANI-SL has extended the standard ORANI-G structure to subdivide the agricultural land factor into rain-fed agricultural land irrigated agricultural land.

Any economic system should allocate its scarce resources among economic agents such as producers, investors, households, non-nationals, and governments for their competing uses. Economics examines how to make choices and its efficiency in allocating these resources among economic agents in an economy. Households make their choices to maximize their utility under budget constraints, while the producers make choices to maximize their profits (minimize their cost) under the production technology constraint. This optimizing of economic agent behaviour will reveal the market price, which is determined by market equilibrium. Hence, this behaviour is capable of being captured in an economy wide general equilibrium framework. 
The basic structure of the ORANI-SL model and the data required to construct a country-specific ORANI -SL model is presented in the figure below (Figure 2). The model is split into a series of demanders listed below:

1. Domestic producers divided by I industries;

2. Investors divided by I industries;

3. A single representative household;

4. An aggregate foreign purchaser of exports;

5. Government demands;

6. Changes in inventories.

\begin{tabular}{|c|c|c|c|c|c|c|c|}
\hline & \multicolumn{6}{|c|}{ Absorption Matrix } \\
\hline & & 1 & 2 & 3 & 4 & 5 & 6 \\
\hline & & Producers & Investors & Households & Exports & Government & $\begin{array}{l}\text { Change in } \\
\text { Inventories }\end{array}$ \\
\hline & Size & I & I & 1 & 1 & 1 & 1 \\
\hline Basic flow & $\mathrm{C} \times \mathrm{S}$ & V1BAS & V2BAS & V3BAS & V4BAS & V5BAS & V6BAS \\
\hline Taxes & $\mathrm{C} \times \mathrm{S}$ & V1TAX & V2TAX & V3TAX & V4TAX & V5TAX & \\
\hline Labour & $\mathrm{O}$ & V1LAB & & & & & \\
\hline Capital & 1 & V1CAP & & & & & \\
\hline Land & $\mathrm{L}$ & V1LND & & & & & \\
\hline $\begin{array}{l}\text { Production } \\
\operatorname{tax}\end{array}$ & 1 & V1PTX & & & & & \\
\hline Other Costs & 1 & V1OCT & & & & & \\
\hline
\end{tabular}

\begin{tabular}{|c|c|}
\hline & Make Matrix \\
\hline Size & I \\
\hline C & MAKE \\
\hline
\end{tabular}

\begin{tabular}{|c|c|}
\hline & Import Duty \\
\hline Size & 1 \\
\hline C & V0TAR \\
\hline
\end{tabular}

C- Number of Commodities (127)

I - Number of Industries (127)

S - Domestic / Import

$\mathrm{O}-$ Number of Occupation types (2)

$\mathrm{L}-$ Number of Land types (2)

Figure 2 : Structure of the ORANI-SL database

Values in each column in the absorption matrix indicate the structure of the purchases made by each demander mentioned under the respective column headings. Firstly, commodities (C) in an economy, obtained either domestically or imported, are used by 
producers as inputs to produce current goods and services (V1BAS) and for capital formation (V2BAS). These commodities are also consumed by households (V3BAS), governments (V5BAS) and are exported (only domestic produced goods) (V4BAS) or are adjusted based on inventories (V6BAS). All these are valued at the basic price.

Secondly, commodity taxes mentioned in the second row, which are associated with the purchases of each agent, are payable by the producers on purchases. Finally, apart from the intermediate inputs, primary factors such as labour (divided into $\mathrm{O}$ occupations) (V1LAB), capital (V1CAP), and land (V1LND, divided into L land types; rain-fed or irrigated) are used for current production. Values in the production tax row (V1PTX) indicate the output taxes or subsidies, while the values in the other cost row (V1OCT) indicate various costs to firms.

Any industry is capable of producing any commodity in the economy. Therefore, the MAKE matrix at the bottom of Figure 2 shows the values of the output of each commodity type produced by each industry. The summation of values in each column in the MAKE matrix must be equal to the total cost of the absorption matrix. By convention, the row totals associated with each commodity in the MAKE matrix must be equal to the total domestic production value of the respective commodity plus the direct and indirect usage of (domestic) margin commodities. The last matrix in Figure 2 represents the import tariff revenue (VOTAR).

Margin values (transport and trade) obtained from Sri Lanka's supply table were added to the I-O table base values. The import duty matrix was created based on the importrelated data mentioned in Sri Lanka's supply table. In addition, the supply table also provides data on indirect taxes and subsidies relevant to each commodity. The data transformation steps conducted to transform I-O table data into the ORANI-SL structure are described below (Figure 2).

\section{$\underline{\text { Investment Matrix }}$}

In the standard Sri Lankan I-O table, the investment or the Gross Fixed Capital Formation (GFCF) is displayed in a single column in the final demand quadrant (Q2) in table 2. The 127-row column vector indicates the total demand for each commodity for fixed capital formation and must be transformed into a 127 commodity by 127 industry matrix to implement the ORANI-SL database represented in figure 2.

As there was no additional information found relating to the investment matrix, the fixed capital formation column values contained in the Sri Lankan I-O table were 
apportioned among the 127 industries based on the input demand and the assumption that larger usage inputs by industries have a greater investment weight.

Table 7: Creation of Investment Matrix

\begin{tabular}{|l|l|l|l|l|l|l|l|l|}
\hline & A & B & C & D & E & F & Total & GFCF \\
\hline A & X & & & & & & TRA & IA \\
\hline B & & & & & & & TRB & IB \\
\hline C & & & & & & & TRC & IC \\
\hline D & & & & & & & TRD & ID \\
\hline E & & & & & & & TRE & IE \\
\hline F & & & & & & & TRF & IF \\
\hline Total & TCA & TCB & TCC & TCD & TCE & TCF & & \\
\hline
\end{tabular}

Where;

TCA is the total of column A

TRA is the total of row A

Therefore, the V2BAS value for cell $\mathrm{X}=(\mathrm{X} / \mathrm{TRA}) \mathrm{x}$ IA.

For example, in the Sri Lankan I-O table, the commodity coffee demand by the chocolate production industry rupees is ' 000 Million 439.1, and the total demand for the commodity coffee by all the industries in the economy is rupees ' 000 Million 1,364.5. The respective GFCF value for the commodity coffee is rupees ' 000 Million 2.4. Therefore, the allocation of investment in commodity coffee by the chocolate production industry is 0.7723 .

Using the above share weight method, data in the I-O table can be transformed to fit the ORANI-SL investment matrix by distributing the Gross Fixed Capital Formation Values according to the intermediate input use matrix. Having created the 127 commodity by 127 industry investment matrix, the next step is to derive the tax matrices.

\section{Tax Matrix.}

The standard I-O table provided by the DCS has only a single row representing taxes less subsidies on domestic production and imports. To develop tax matrices, it is vital to separate taxes on domestic production and taxes on imports. Fortunately, the DCS supply table makes this distinction and presents taxes on domestic production and on imports for each commodity or product in separate columns. Thus, the domestic production taxes column in the supply table was expanded among the 127 industries 
based on the input demand of the domestic production matrix and, similarly, the taxes on imports column was expanded among 127 industries based on the input demand of the imports matrix. The method is similar to the data transformation procedure of the investment matrix.

The Row and Sum (RAS) procedure is conducted to ensure that the taxes less subsidies on products column in the supply table and taxes less subsidies in production and imports row in the I-O table obey the row and column restrictions. This method is eliminates minor inconsistencies arising during the manipulation of data obtained from two different sources; the supply table and I-O table. The taxes less subsidies on products column total in the supply table was equal to the taxes less subsidies in production and imports row total in I-O table. Also, the data manipulated were not very far away from the targeted columns/rows. According to M Horridge (2001), the RAS method will fail to meet the requirement of target row totals being equal to the sum of target column totals when there is a huge difference between some of the target row and column totals in the original matrix or if some of the components of the original matrix are not positive.

Resultant values, other raw data in the I-O table, and elasticity values were saved in the Header Array files (HAR files) in an appropriate form. HAR files are binary files used in the GEMPACK program. Therefore, all the ORANI-SL model data were saved in HAR files and can be viewed using a special program called ViewHAR.

\section{Conclusion}

This paper presents a new version of the ORANI-G model known as the ORANI-SL, which is a regional CGE model developed for Sri Lanka. The new model's production structure uses water as a factor of production in the agricultural sector and enables substitution between rain-fed and irrigated lands. To the best of our knowledge, this is the first CGE model that differentiates rain-fed and irrigated agricultural land in Sri Lanka. However, similar studies can be found in other countries. This paper provides a detailed description of the new production structure and the implementation of the new model's database.

The new model facilitates the assessment of the economy wide impacts of climate change and alternative adaptation strategies against climate change in Sri Lanka. Thus, policymakers can prioritize adaptation strategies to mitigate the impacts of climate change based on its economic impacts. Further, it enables the modelling of green and 
blue water usage in the agricultural sector in Sri Lanka. The author proposes to use this model to analyse the economic impacts of climate change in Sri Lanka, evaluate how enhanced irrigation capacity in the agricultural sector could sustain the national economy, and analyse the economy wide impacts of other adaptation strategies to mitigate climate change.

However, the ORANI-SL only considers water usage in the agricultural sector and neglects usage in households and industries. Therefore, future development of the ORANI-SL model could consider this limitation and incorporate home and industry water usage into the model.

\section{$\underline{\text { References }}$}

Ahmed, M., \& Suphachalasai, S. (2014). Assessing the costs of climate change and adaptation in South Asia: Asian Development Bank.

Barrett, C. B. (2010). Measuring food insecurity. Science, 327(5967), 825-828.

Berck, P., Robinson, S., \& Goldman, G. (1991). The use of computable general equilibrium models to assess water policies The economics and management of water and drainage in agriculture (pp. 489-509): Springer.

Berrittella, M., Hoekstra, A. Y., Rehdanz, K., Roson, R., \& Tol, R. S. (2007). The economic impact of restricted water supply: A computable general equilibrium analysis. Water research, 41(8), 1799-1813.

Calzadilla, A., Rehdanz, K., Roson, R., Sartori, M., \& Tol, R. S. (2017). Review of CGE models of water issues WORLD SCIENTIFIC REFERENCE ON NATURAL RESOURCES AND ENVIRONMENTAL POLICY IN THE ERA OF GLOBAL CHANGE: Volume 3: Computable General Equilibrium Models (pp. 101-123): World Scientific.

Calzadilla, A., Rehdanz, K., \& Tol, R. S. (2010). The economic impact of more sustainable water use in agriculture: A computable general equilibrium analysis. Journal of Hydrology, 384(3-4), 292-305.

Calzadilla, A., Rehdanz, K., \& Tol, R. S. (2011a). The GTAP-W model: Accounting for water use in agriculture. Retrieved from

Calzadilla, A., Rehdanz, K., \& Tol, R. S. (2011b). Water scarcity and the impact of improved irrigation management: a computable general equilibrium analysis. Agricultural Economics, 42(3), 305-323.

Calzadilla, A., Zhu, T., Rehdanz, K., Tol, R. S., \& Ringler, C. (2013). Economywide impacts of climate change on agriculture in Sub-Saharan Africa. Ecological economics, 93, 150-165.

Cline, W. R. (2007). Global warming and agriculture: Impact estimates by country: Peterson Institute.

De Costa, W. (2008). Climate change in Sri Lanka: myth or reality? Evidence from long-term meteorological data. Journal of the National Science Foundation of Sri Lanka, 36, 63-88.

De Costa, W. (2010). Adaptation of agricultural crop production to climate change: a policy framework for Sri Lanka. Journal of the National Science Foundation of Sri Lanka, 38(2). 
De Silva, C. (2009). Climate Change Effects on the North-East Monsoon and Dry Zone Agriculture in Sri Lanka. Paper presented at the Global Climate Change and its Impacts on Agriculture, Forestry and Water in the Tropics, Kandy, Sri Lanka.

Decaluwe, B., Patry, A., \& Savard, L. (1999). When water is no longer heaven sent: Comparative pricing analysis in a AGE model. Retrieved from

Dharmaratna, D., \& Parasnis, J. (2010). Price responsiveness of residential, industrial and commercial water demand in Sri Lanka. University of Monash Discussion Paper, 44(10).

Diao, X., \& Roe, T. (2000). The win-win effect of joint water market and trade reform on interest groups in irrigated agriculture in Morocco. The political economy of water pricing reforms., 141-165.

Dixon, P., Rimmer, M. T., \& Wittwer, G. (2009). Modelling the Australian government's buyback scheme with a dynamic multi-regional CGE model: Centre of Policy Studies (CoPS).

Dixon, P. B. (1982). Orani, a multisectoral model of the Australian economy (Vol. 142): North Holland.

Eeswaran, R. (2018). Climate Change Impacts and Adaptation in the Agriculture Sector of Sri Lanka: What We Learnt and Way Forward Handbook of Climate Change Communication: Vol. 2 (pp. 97-110): Springer.

Esham, M., \& Garforth, C. (2013). Climate change and agricultural adaptation in Sri Lanka: a review. Climate and Development, 5(1), 66-76.

Godfray, H. C. J., Beddington, J. R., Crute, I. R., Haddad, L., Lawrence, D., Muir, J. F., . . Toulmin, C. (2010). Food security: the challenge of feeding 9 billion people. Science, 1185383.

Gohin, A., \& Hertel, T. (2003). A note on the CES functional form and its use in the GTAP model.

Gomez, C. M., Tirado, D., \& Rey-Maquieira, J. (2004). Water exchanges versus water works: Insights from a computable general equilibrium model for the Balearic Islands. Water Resources Research, 40(10).

Horridge, J. (2000). ORANI-G: A general equilibrium model of the Australian economy: Centre of Policy Studies (CoPS).

Horridge, M. (2001). DAGG Guide: A multipurpose freeware software package for manipulating and balancing databases. University of Monash, Melbourne, Australia.

Horridge, M. (2003). ORANI-G: A generic single-country computable general equilibrium model. Centre of Policy Studies and Impact Project, Monash University, Australia.

Horridge, M., \& Wittwer, G. (2008). SinoTERM, a multi-regional CGE model of China. China Economic Review, 19(4), 628-634.

Kohli, A., Frenken, K., \& Spottorno, C. (2010). Disambiguation of water use statistics. The AQUASTAT Programme of FAO, Rome, Italy.

Lkhanaajav, E. (2016). CoPS-style CGE modelling and analysis: Centre of Policy Studies (CoPS), Victoria University.

Mendelsohn, R. (2008). The impact of climate change on agriculture in developing countries. Journal of Natural Resources Policy Research, 1(1), 5-19.

Mukherjee, N. (1996). Water and land in South Africa: economywide impacts of reform--a case study for the Olifants river. Retrieved from

Panabokke, C., \& Punyawardena, B. (2010). Climate change and rain-fed agriculture in the dry zone of Sri Lanka. Paper presented at the Proceedings of the national 
conference on water, food security and climate change in Sri Lanka. Volume 2: water quality, environment and climate change. Colombo, 9-11 June, 2009.

Peterson, D., Dwyer, G., Appels, D., \& Fry, J. (2005). Water trade in the southern Murray-Darling Basin. Economic Record, 81, S115-S127.

Peterson, D. C., Dwyer, G., Appels, D., \& Fry, J. M. (2004). Modelling water trade in the southern Murray-Darling Basin.

Premalal, K. (2009). Climate Change in Sri Lanka. Paper presented at the Global Climate Change and its Impacts on Agriculture, Forestry and Water in the Tropics Kandy, Sri Lanka.

Robinson, S., \& Gehlhar, C. G. (1995). Land, water, and agriculture in Egypt: The economywide impact of policy reform. Retrieved from

Roson, R., \& Sartori, M. (2015). System-wide implications of changing water availability and agricultural productivity in the Mediterranean economies. Water Economics and Policy, 1(01), 1450001.

Sahlén, L. (2008). The impacts of food-and oil price shocks on the Namibian economy: The role of water scarcity. Umea University. Retrieved February, 22, 2009.

Seung, C. K., Harris, T. R., MacDiarmid, T. R., \& Shaw, W. D. (1998). Economic impacts of water reallocation: A CGE analysis for walker river basin of Nevada and California. Journal of Regional Analysis and Policy, 28(11002016-89752), 13-34.

Taheripour, F., Hertel, T. W., \& Liu, J. (2013). Water reliability, irrigation adoption, and land use changes in the presence of biofuel production.

Tirado, D., Gomez, C. M., \& Lozano, J. (2006). Efficiency improvements and water policy in the Balearic Islands: a general equilibrium approach. investigaciones económicas, 30(3), 441-463.

van Heerden, J. H., Blignaut, J., \& Horridge, M. (2008). Integrated water and economic modelling of the impacts of water market instruments on the South African economy. Ecological economics, 66(1), 105-116. 
Annex 1:

Source of water composition of Land demand

E_x1lnd \# Demand for Land by industry and water source \# (all, i, IND) (all, z, WTR)

$x 1 \operatorname{lnd}(i, z)=x 1 \operatorname{lnd} z(i)-\operatorname{SIGMA} 1 \operatorname{LND}(i) *[p 1 \operatorname{lnd}(i, z)-$

p1lnd_z(i)];

E_p1lnd_z \# Price to each industry of Land composite \# (all, i, IND)

[TINY+V1LND_Z(i)]*p1lnd_z(i) $=\operatorname{sum}\{z, W T R$, $\operatorname{V1LND}(i, z) * p 1 \operatorname{lnd}(i, z)\}$;

Primary factor proportions

E_x1lab_o \# Industry demands for effective Labour \# $(a 11, i, I N D)$

$x 11 a b \_o(i)-a 11 a b \_o(i)=x 1 p r i m(i)-S I G M A 1 P R I M(i) *\left[p 11 a b \_o(i)+\right.$ a1lab_o(i)-p1prim(i)];

E_x1cap \# Industry demands for capital \#

$(a 11, i, I N D)$

$x 1 \operatorname{cap}(i)-\operatorname{a1cap}(i)=x 1 p r i m(i)-\operatorname{SIGMA1PRIM}(i) *[p 1 c a p(i)+$ a1cap(i)-p1prim(i)];

E_x1lnd_z \# Industry demands for Land \#

$(a l l, i, I N D)$

$x 11 n d z z(i)-a 11 n d \_z(i)=x 1 p r i m(i) \operatorname{SIGMA1PRIM}(i) *\left[p 11 n d \_z(i)+\right.$ a1lnd_z(i)-p1prim(i)];

E_p1prim \# Effective price term for factor demand equations \#

$(a 11, i, I N D)$ V1PRIM(i)*p1prim(i) = V1LAB_O(i)*[p1lab_o(i) + a1lab_o(i)]

$+\operatorname{V1CAP}(i) *[p 1 c a p(i)+\operatorname{arcap}(i)]+\operatorname{V1LND} Z$ Z(i)*[p11nd_z(i)

+ a1lnd_z(i)];

E_delV1PRIM \# Ordinary change in total cost of primary factors\#

$(a 11, i, I N D) 100 * \operatorname{delV1PRIM}(i)=\operatorname{V1CAP}(i) *[p 1 \mathrm{cap}(i)+$ $x 1 \operatorname{cap}(i)]$

$+V 1 L N D \_Z(i) *\left[p 11 n d \_z(i)+x 11 n d \_z(i)\right]$

$+\operatorname{sum}\{0,0 C C, \operatorname{V1LAB}(i, 0) *[p 11 a b(i, 0)+x 11 a b(i, 0)]\}$ 
Annex 2:

Annex 2: Aggregated I-O Table of Sri Lanka

USERS

\begin{tabular}{|c|c|c|c|c|c|c|c|c|c|c|c|c|c|c|c|c|}
\hline & & \multicolumn{9}{|c|}{ Intermediate Demand } & \multirow[b]{2}{*}{$\begin{array}{l}\text { Final } \\
\text { Consumpt } \\
\text { ion }\end{array}$} & \multirow[b]{2}{*}{$\begin{array}{l}\text { Gross } \\
\text { Capital } \\
\text { Formation }\end{array}$} & \multirow[b]{2}{*}{$\begin{array}{l}\text { Total } \\
\text { Exports }\end{array}$} & \multirow[b]{2}{*}{ Total Imports } & \multirow[b]{2}{*}{$\begin{array}{l}\text { Total Final } \\
\text { Demand }\end{array}$} & \multirow[b]{2}{*}{ Total demand } \\
\hline & & $\begin{array}{l}\text { Growing } \\
\text { of rice }\end{array}$ & $\begin{array}{l}\text { Growing } \\
\text { of } \\
\text { beverage } \\
\text { crops } \\
\text { Tea }\end{array}$ & $\begin{array}{l}\text { Growing } \\
\text { of } \\
\text { Rubber }\end{array}$ & Fishing & $\begin{array}{l}\text { Other } \\
\text { Agricultu } \\
\text { re } \\
\text { industrie } \\
s\end{array}$ & \begin{tabular}{|l} 
Aggriculture \\
related \\
manufactu \\
ring
\end{tabular} & $\begin{array}{l}\text { other } \\
\text { manufact } \\
\text { uring }\end{array}$ & Services & $\begin{array}{l}\text { Total } \\
\text { Intermediat } \\
\text { e Demand }\end{array}$ & & & & & & \\
\hline & Growing of rice & 4701.7 & 0.2 & 0.2 & 0.4 & 35.6 & 75637.7 & 25.8 & 11489.0 & 91890.5 & 9377.4 & 8831.3 & 86.8 & \begin{tabular}{|c|}
-1025.3 \\
\end{tabular} & 17270.2 & 109160.7 \\
\hline & \begin{tabular}{|l|} 
Growing of \\
beverage crops \\
Tea
\end{tabular} & 0.7 & 0.2 & 0.2 & 0.4 & 1.1 & 81763.3 & 67.1 & 94.6 & 81927.8 & 593.0 & 2218.4 & 228.7 & -67.1 & 2973.0 & 84900.7 \\
\hline & \begin{tabular}{|l|} 
Growing of \\
Rubber \\
\end{tabular} & 0.0 & 0.0 & 0.0 & 0.0 & 0.0 & 46131.3 & 0.0 & 0.0 & 46131.3 & ${ }^{0.0}$ & -199.3 & 16474.8 & -4229.2 & 12046.4 & 58177.7 \\
\hline & \begin{tabular}{|l|} 
Fishing \\
\end{tabular} & 25.8 & 3.0 & 4.1 & $\begin{array}{ll}1313.7 \\
\end{array}$ & 18.7 & 14068.6 & 386.6 & 8145.2 & 23965.6 & 87675.4 & 3252.7 & 2583.8 & .345 .9 & 93165.9 & 117131.5 \\
\hline & $\begin{array}{l}\begin{array}{l}\text { Other Agriculture } \\
\text { industries }\end{array} \\
\end{array}$ & 180.7 & 24.3 & 96.2 & 381.7 & 14186.7 & 109744.3 & 22888.9 & 12022.9 & 159525.7 & 255351.3 & 11110.8 & 18645.3 & -85688.0 & 199419.4 & 358945. \\
\hline & \begin{tabular}{|l|} 
Agriciculture \\
related \\
manufacturing
\end{tabular} & 44352.0 & 5972.6 & 2139.1 & 342.8 & 35125.6 & 138103.6 & 32490.0 & 89664.5 & 348190.2 & 721749.6 & 44521.5 & 222173.5 & -199242.4 & 789202.2 & 1137392.3 \\
\hline & $\begin{array}{l}\text { other } \\
\text { manufacturing }\end{array}$ & 3895.6 & 1884.2 & 7244.1 & 28423.5 & 7827.8 & 44387.3 & 969578.4 & 534441.3 & 1597682.1 & 461677.9 & 1316857.7 & 538140.5 & -1211048.8 & 1105627.4 & 2703309.5 \\
\hline & \begin{tabular}{|l|} 
Services \\
\end{tabular} & 15022.0 & 3603.1 & 2632.1 & 6055.8 & 15488.3 & 116859.7 & 375656.6 & 952220.1 & 1487537.7 & 3194501.0 & 358566.1 & 360063.4 & -162407.4 & 3750723.1 & 5238260.8 \\
\hline I & \begin{tabular}{|l} 
Direct Purchases \\
in Domestic \\
Market by Non- \\
Riesidents
\end{tabular} & 0.0 & 0.0 & 0.0 & 0.0 & 0.0 & 0.0 & 0.0 & 0.0 & 0.0 & -67356.0 & 0.0 & 67356.0 & 0.0 & 0.0 & 0.0 \\
\hline $\begin{array}{l}\mathbf{N} \\
\mathbf{P}\end{array}$ & \begin{tabular}{|l} 
Direct Purchases \\
Abroad by \\
Riesidents \\
\end{tabular} & 0.0 & 0.0 & 0.0 & 0.0 & 0.0 & 0.0 & 0.0 & 0.0 & 0.0 & 55551.0 & 0.0 & 0.0 & -55551.0 & 0.0 & 0.0 \\
\hline $\mathbf{U}$ & \begin{tabular}{|l|} 
Intermediate \\
Inputs
\end{tabular} & 68178.5 & 11487.6 & 12115.9 & 36518.2 & 72683.8 & 626695.8 & 1401093.4 & 1608077.6 & 3836850.8 & 4719120.6 & 1745159.2 & 1225752.7 & -1719605.0 & 5970427.5 & 9807278.3 \\
\hline $\mathbf{T}$ & \begin{tabular}{|l|} 
Takes less \\
subsidies on \\
production and \\
imports
\end{tabular} & -19103.9 & 1205.5 & 1650.8 & -6701.9 & 5365.8 & 26032.6 & 93584.9 & 110289.5 & 212323.2 & 213423.4 & 201549.2 & 28268.3 & 0.0 & 443240.9 & 655564.2 \\
\hline S & \begin{tabular}{|l|} 
Total \\
Intermediate \\
Inputs
\end{tabular} & 49074.6 & 12693.0 & $\mid 13766.7$ & 29816.3 & 78049.5 & 652728.4 & 1494678.4 & 1718367.1 & 4049174.1 & 4932544.0 & 1946708.4 & 1254021.0 & -1719605.0 & 6413668.5 & 0.0 \\
\hline & $\begin{array}{l}\text { Compensation o } \\
\text { employees }\end{array}$ & 18542.1 & 34833.3 & 18102.1 & 32195.1 & 58541.8 & 51775.6 & 229444.5 & 1234886.3 & 1678320.8 & 0.0 & 0.0 & 0.0 & 0.0 & 0.0 & 0.0 \\
\hline & $\begin{array}{l}\text { Other taskes less } \\
\text { subsidies on } \\
\text { production }\end{array}$ & 0.0 & 0.0 & 0.0 & 0.0 & 0.0 & 152.5 & 3599.9 & 26142.6 & 29895.0 & 0.0 & 0.0 & 0.0 & 0.0 & 0.0 & 0.0 \\
\hline & $\begin{array}{l}\text { Mixed income. } \\
\text { net }\end{array}$ & 22760.7 & 9574.7 & 9210.8 & 16532.1 & 117404.1 & 13933.4 & 55085.7 & 164317.3 & 408818.9 & 0.0 & 0.0 & 0.0 & 0.0 & 0.0 & 0.0 \\
\hline & $\begin{array}{l}\begin{array}{l}\text { Operating surplus } \\
\text { net }\end{array} \\
\end{array}$ & 16229.7 & 26860.9 & 16565.1 & 18216.6 & 94105.0 & 404000.6 & 834606.3 & 1843769.6 & 3254353.8 & 0.0 & 0.0 & 0.0 & 0.0 & 0.0 & 0.0 \\
\hline & $\begin{array}{l}\begin{array}{l}\text { Consumption of } \\
\text { fised capital }\end{array} \\
\end{array}$ & 2553.7 & 938.7 & 532.9 & $|20371.5|$ & 10844.7 & 14801.8 & 85896.5 & 250776.5 & 386716.3 & 0.0 & 0.0 & 0.0 & 0.0 & 0.0 & 0.0 \\
\hline & $\begin{array}{l}\text { Total Gross } \\
\text { Value Added }\end{array}$ & 60086.2 & 72207.7 & 44410.9 & 87315.2 & 280895.6 & 484663.9 & 1208632.9 & 3519892.3 & \begin{tabular}{|l|}
5758104.7 \\
\end{tabular} & 0.0 & 0.0 & 0.0 & 0.0 & 0.0 & 0.0 \\
\hline & \begin{tabular}{|l|l|l|l|} 
Total inputs \\
\end{tabular} & 109160.7 & 84900.7 & \begin{tabular}{|l|}
58177.7 \\
\end{tabular} & \begin{tabular}{|l|}
117131.5 \\
\end{tabular} & $5 \longdiv { 3 5 8 9 4 5 . 2 }$ & 1137392.3 & 2703311.3 & \begin{tabular}{|l|}
5238259.4 \\
\end{tabular} & \begin{tabular}{|l|}
9807278.7 \\
\end{tabular} & 0.0 & 0.0 & 0.0 & 0.0 & 0.0 & 9807278.7 \\
\hline
\end{tabular}


Figures

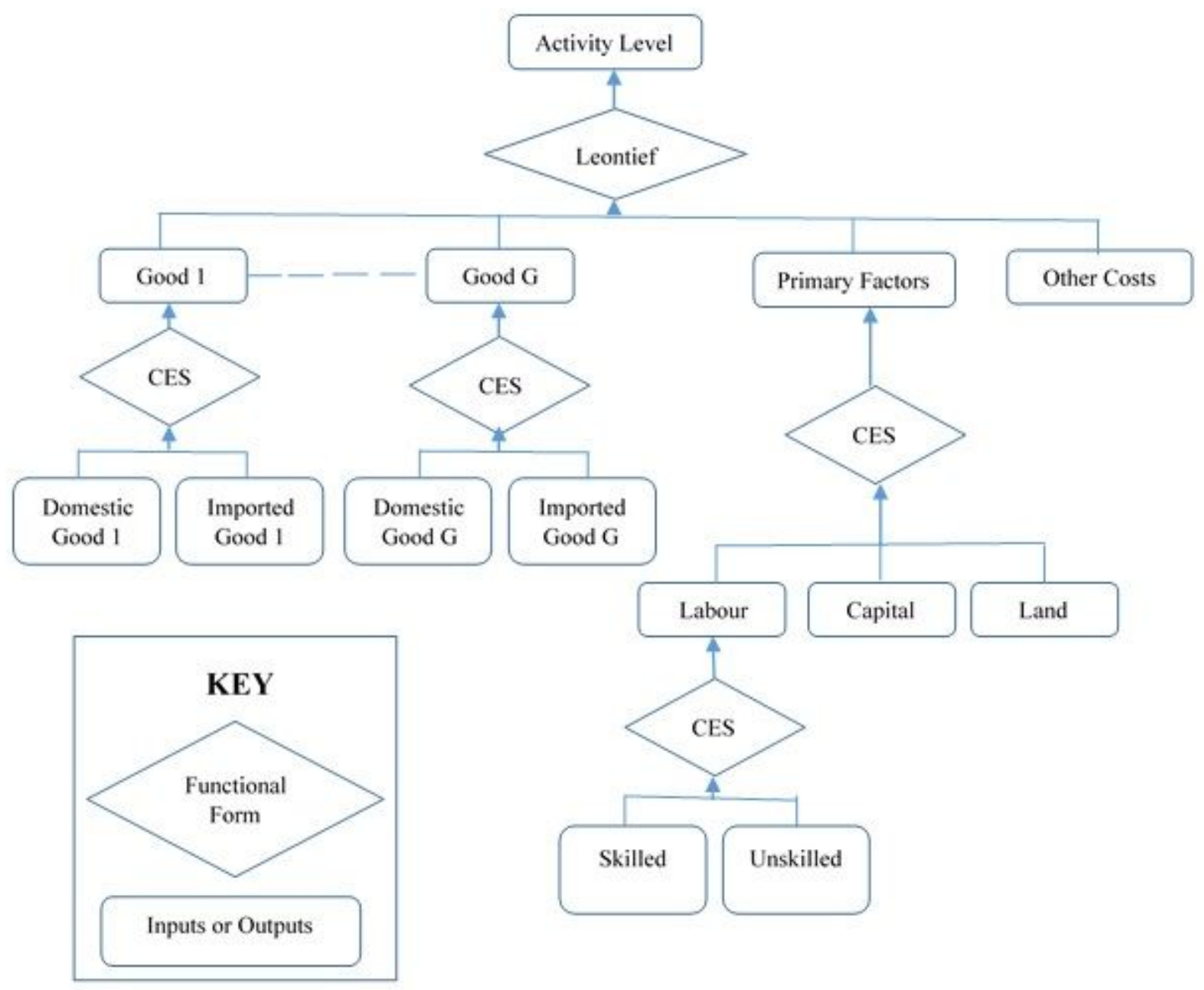

Figure 1

Model Production Function 


\begin{tabular}{|c|c|c|c|c|c|c|c|}
\hline & \multicolumn{6}{|c|}{ Absorption Matrix } \\
\hline & & 1 & 2 & 3 & 4 & 5 & 6 \\
\hline & & Producers & Investors & Households & Exports & Government & $\begin{array}{l}\text { Change in } \\
\text { Inventories }\end{array}$ \\
\hline & Size & I & I & 1 & 1 & 1 & 1 \\
\hline Basic flow & $\mathrm{CxS}$ & V1BAS & V2BAS & V3BAS & V4BAS & V5BAS & V6BAS \\
\hline Taxes & $\mathrm{CxS}$ & V1TAX & V2TAX & V3TAX & V4TAX & V5TAX & \\
\hline Labour & $\mathrm{O}$ & V1LAB & & & & & \\
\hline Capital & 1 & V1CAP & & & & & \\
\hline Land & $\mathrm{L}$ & V1LND & & & & & \\
\hline $\begin{array}{l}\text { Production } \\
\operatorname{tax}\end{array}$ & 1 & V1PTX & & & & & \\
\hline Other Costs & 1 & V1OCT & & & & & \\
\hline
\end{tabular}

\begin{tabular}{|c|c|}
\hline & Make Matrix \\
\hline Size & I \\
\hline C & MAKE \\
\hline
\end{tabular}

\begin{tabular}{|c|c|}
\hline & Import Duty \\
\hline Size & 1 \\
\hline C & VOTAR \\
\hline
\end{tabular}

C- Number of Commodities (127)

I - Number of Industries (127)

$\mathrm{S}$ - Domestic / Import

O-Number of Occupation types (2)

L - Number of Land types (2)

\section{Figure 2}

Structure of the ORANI-SL database 